NBER WORKING PAPER SERIES

\title{
GAUCHO BANKING REDUX
}

\author{
Gerardo della Paolera \\ Alan M. Taylor \\ Working Paper 9457 \\ http://www.nber.org/papers/w9457
}

\section{NATIONAL BUREAU OF ECONOMIC RESEARCH 1050 Massachusetts Avenue \\ Cambridge, MA 02138}

January 2003

We thank Andrés Velasco, an anonymous referee, and conference participants at LACEA for their helpful comments, and Carlos Bozzoli for his research assistance. Taylor gratefully acknowledges the support of the Chancellor's Fellowship at the University of California, Davis. All errors are ours. The views expressed herein are those of the authors and not necessarily those of the National Bureau of Economic Research.

(C)2003 by Gerardo della Paolera and Alan M. Taylor. All rights reserved. Short sections of text not to exceed two paragraphs, may be quoted without explicit permission provided that full credit including notice, is given to the source. 
Gauch Banking Redux

Gerardo della Paolera and Alan M. Taylor

NBER Working Paper No. 9457

January 2003

JEL No. E42, E44, E51, E61, E65, G21, N16, N26

\begin{abstract}
Argentina's economic crisis has strong similarities with previous crises stretching back to the nineteenth century. A common thread runs through all these crises: the interaction of a weak, undisciplined, or corruptible banking sector, and some other group of conspirators from the public or private sector that hasten its collapse. This pampean propensity for crony finance was dubbed "gaucho banking" more than one hundred years ago. What happens when such a rotten structure interacts with a convertibility plan? We compare the 1929 and 2001 crises_- the two instances where rigid convertibility plans failed_—and reach two main conclusions. First, a seemingly robust currency-board can be devastated by an ill-conceived approach to the problems of internal and external convertibility (or, to rephrase Gresham, "bad inside money drives out good outside money"). Second, when modern economic orthodoxy collides with caudillo-style institutional backwardness, a desperate regime with its hands tied in both monetary and fiscal domains will be sorely tempted by a "capital levy" on the financial sector (for, as Willie Sutton said when asked why he robbed banks, "because that's where the money is").
\end{abstract}

Gerardo della Paolera

The American University of Paris

6 , rue de Colonel Combes

75007 Paris

France

gerry@aup.fr
Alan M. Taylor

Department of Economics University of California, Davis

Davis, CA 95616

and NBER

amtaylor@ucdavis.edu 


\section{Argentina's Crisis in Historical Perspective}

An Argentine economic experiment has come to an ignominious end. The attempt to establish a stable currency has given way to an unplanned float and a fourfold devaluation has rendered null any chance of restoring the old parity. In addition to a widespread economic malaise following some years of a boom, one of the major casualties of the crisis is the banking sector, where triage is minimal and the search for a long-run cure has barely begun. The fiscal health of the government remains under a cloud of suspicion. Foreign investors in government bonds, already badly burned, are ill disposed toward the country when such assistance is badly needed. All agree that the political class has failed and some observers have suggested that nothing less then placing the country in "economic receivership" and turning its affairs over to an independent foreign administrator will rectify the situation:

Investors here, with minds disorganized by the fate which has overtaken those concerned in the reckless speculations and borrowings of the past years, seem to conclude that Argentina is ruined because they, themselves, have lost money. Reckless speculators in the Argentine republic have lost money because they carried their speculation to undue lengths; but the Argentines have profited and the country is profiting by the sowing broad-cast of [foreign] capital in the country.

A solid administration is required under an honest President. Some assistance in the formation of a bank upon sounds principles is needed, with improvement in the currency. It is possible that the system of taxation might be varied so as to provide for the provincial and municipal loans which were too readily granted; though probabilities disincline an observer to conclude that local taxation will be increased without great difficulty.

Suggestions have been hazarded relative to foreign financial control. Foreign financial control may be needed, and may be possible in the case of a feeble or a decaying state. ${ }^{1}$

As the reader may have guessed from the florid tone and antiquated style of this prose, the year is not 2002. It is 1891. A certain W. H. Bishop is writing for a new publication called the Economic Journal as Argentina gropes its way through the wreckage of what we have previously characterized as the world's first fully-fledged emerging market crisis, the Baring Crash of $1890{ }^{2}$ As is well known, the year 1890 has stood ever since in the Argentine historiography as a fateful year of unmatched economic calamity.

\footnotetext{
${ }^{1}$ In the original "foreign" reads "European."

${ }^{2}$ In the historical treatment our work draws on della Paolera and Taylor (2001).
} 
Given the scale of the present crisis, and the economic, social, and political wounds it has opened up, we think that from now on Argentine economic history will be rewritten from a very different perspective and 2001 will be on center stage. Yet the lessons from the past are hauntingly familiar, and, as is perhaps obvious, are here once again to be relearned. How will history be rewritten? It is not just that we think the events of 2001-02 are more catastrophic than those of 1890-91. Indeed, Argentina has suffered a steady stream of economic crises throughout her history, and one purpose of this article is to highlight the common features of these episodes and place the present debacle in some historical perspective. Yet we will also be careful to spell out the important differences that separate the present from the past.

In this paper we argue that the inability of Argentina to ever develop sound banking institutions doomed to failure all the attempts that were made to reform the monetary regime using exchange-rate based stabilizations. In other words, we see the "twin crisis" problem, as noted by Kaminsky and Reinhart (1999) as being endemic in the Argentine economy given the underlying structures. This begs the question: what are the problematic structures that have never been properly fixed?

At the deepest level, the "crony leadership" problem for Argentina is akin to that of other developing countries, such as the Asian economies faulted for their "crony capitalism" after the 1997 crises, though important differences remain. The failure of key banking and financial institutions to follow prudent, transparent, accountable, and non-corrupt practices is, we think, as central to understanding the Argentine crisis of 2001 as the Asian crisis of 1997. It is also a recurring theme in the long history of Argentine crises noted in Table 1. There is, in fact, a much older name for this phenomenon. When this problem first emerged on the River Plate, a memorable moniker was crafted by our correspondent, the same Lawson, who wrote of the Baring Crash in his 1891 article "Gaucho Banking":

[Argentine banks] were free banks in the freest sense of the term, for any Gaucho who had the political open sesame to them could ask for almost anything he pleased, and it would be given him so long as there was a piastre left in the till. ${ }^{3}$

We resurrect the term Gaucho Banking, and what we mean by that is the fragility that results from the mix of two ingredients. First, the fiscal policy and exchange rate linkage implied by a currency board type of regime. Second, the existence of bank created money due to a fractional reserve banking system. Or, put another way, the internal-external convertibility tension that exposes all such regimes to a risk of collapse due to the twin problems of no lender of last resort and a classic "gold standard" type monetary equilibrium-because, as is occasionally forgotten, one cannot attain two goals with a single instrument. The general message of this paper

\footnotetext{
${ }^{3}$ Banker's Magazine (1891, p. 38), quoted in Ford (1962, p. 100).
} 
is that if the government's budget constraint is inconsistent (fiscal pollution) the problem of "unpleasant fiscal arithmetic" might not be contained, and without resistance from other putative sources of fiscal revenue (here, the banks) the problem could spill over into a destruction of other institutions through inappropriate political economy choices.

This is how we read the Argentine dynamics of the second quarter of 2001. Changing the convertibility laws appeared might have appeared innocent to some at first glance, because the international reserves were not touched, so base money looked sound. Yet the institutional change, by allowing banks to significantly integrate the bank reserves and government bonds on their balance sheets, eroded public confidence in bank-created money. The subsequent so-called "megaswap" by the government pushed even more public bonds into the banks in exchange for reserves and pushed the process still further.

Here, we think that the banks should be viewed as accomplices rather than victims, because they showed no resistance to "moral" suasion by the authorities. Indeed many welcomed the chance to earn big returns in the short run. Their choice was, they thought, a safe bet: high yields if the plan worked, and a freeze/bailout (or pesification) if it didn't. ${ }^{4}$ (And they were right, as it turned out.) This, for us, is the key institutional shock that, viewed through a model of internal and external convertibility, took the Argentine economy out of a stable dynamic path and onto the highway to hell.

It is important to state here, that we think this particular set of policy choices represents a unique (and uniquely bad) way to handle a crisis, even by the admittedly weak standards of Argentine economic history. In terms of economic losses, Table 1 shows that this crash appears to be more severe than anything seen before, even the harsh downturn of 1914 (which, in turn, exceeded the Baring Crash in depth and duration). ${ }^{5}$ It is also clear that the special exchange rate arrangements that prevailed at the onset the present crisis have been present during only one previous crisis - that of 1929—when the country's first currency board, created in 1891 after the Baring Crash, finally met its demise. Accordingly, we make the case for our comparative approach, one that will center on two analytic narratives, one for the 1929 crash and one for the 2001 crash, where we find the parallels strongest.

Table 1 shows the major "twin crisis" episodes involving the collapse of hard or soft exchange rate pegs since the unification of the modern Argentine state in 1862, and a

\footnotetext{
${ }^{4}$ By "pesification" we mean a change in the law of contracts such that contracts denominated ex ante in U.S. dollars (including bank deposits and loans) would instantly become "de-dollarized" contacts by fiat, and would ex post be in the same amount but in Argentine pesos. On the intellectual origins of this idea see Hausmann (2001).

${ }^{5}$ Output is about $22 \%$ below the 1998 peak based on current data. Even with $5 \%$ growth for four years (which not even the most optimistic forecasts allow) this would generate a situation where the economy spends 8 years below its previous peak. This surpasses all previous experience.
} 
classification of the monetary and banking arrangements is given. ${ }^{6}$ Exchange rate experiments throughout Argentine history have generally oscillated between periods of very loose floating (or "freely falling," as Reinhart and Rogoff 2002 say), and periods of more or less hard pegs. The gold and dollar standards backed by currency boards were the harder regimes, and the dirty floats and crawling pegs rather softer. The willingness to experiment so freely with different regimes is, of course, a time-honored tradition in Argentina, and indeed all of Latin America, creating the kind of reputational problems noted by the English correspondent W. R. Lawson in 1899:

[South Americans] are always in trouble about their currency. Either it is too good for home use, or, as frequently happens, it is too bad for foreign exchange. Generally they have too much of it, but their own idea is that they never have enough.... The Argentines alter their currency almost as frequently as they change their presidents.... No people in the world take a keener interest in currency experiments than the Argentines. ${ }^{7}$

Just as exchange rate regimes have changed over time, so have banking regimes-at least on first glance. The Baring Crash was quite distinct in that it occurred under a heterodox banking experiment known as the Law of National Guaranteed Banks, an unsustainable regulatory framework that was replete with moral hazard and other defects, and which was swept away after 1890. Thereafter, banks were regulated by the commercial code until the 1930 s with no special banking code whatsoever. Although the Central Bank was given broad responsibilities for banking oversight at its creation in 1935, it was not until comprehensive banking laws were promulgated in 1977 that any modern basis for oversight was set in place—not that any of these regimes have prevented banking crises, of course, as the table clearly shows.

Looking at real economic costs, the table shows that painful crises have been associated with the demise of both hard and soft pegs. For example, in 1890 the Argentine regime had floated away from gold parity by a cumulative $100 \%$ over the previous five years of overheated boom; the Baring Crash accelerated existing nominal movements, and sharply reversed real growth trends. With purchasing power parity holding fairly strictly for this economy throughout its history, and with half-lives of adjustment of two years or so, it is not surprising to see exchange rates and prices track each other so closely, except in the case of the global inflation after 1914 and deflation after 1929, times when the foreign price level was more volatile.

\footnotetext{
${ }^{6}$ The crisis of the 1870 s, although very important in economic terms, did not embody all of the twin crisis attributes that would allow us to choose it as the earlier example of a modern emerging-market twin crisis. In that crisis the Avellaneda administration faced unsustainable deficits and debt service burdens inherited from the preceding Sarmiento administration. The response in the short run was to monetize the fiscal gap without any major adjustment in the fundamentals. Predictably, the exchange rate eventually collapsed, but no major banking crisis occurred, and we can see that this episode has all the hallmarks of a classic "first generation" speculative attack model (Krugman 1979), and none of the more complex attributes of a twin crisis such as was seen in 1890 or 2001 . Accordingly, we do not focus on the 1870s crisis here.

${ }^{7}$ Banker's Magazine (1899, p. 691), quoted in Ford (1962, p. 90).
} 
With a little bit of guesswork, Table 1 suggests that the present crisis might break all records for output losses; as noted, output is far below the peak of 1997-98, may go still lower, and seems unlikely to regain its former peak before 2005 based on even the most optimistic projections. Judging by the nominal criteria, this crisis has thus far avoided the hyperinflationary tendencies of the 1980s collapses, but nominal adjustments have already matched or exceeded those seen during the Baring Crash, and certainly anything witnessed during the breaks in earlier hard pegs in 1914 and 1929.

Lastly, the table shows some monetary and banking statistics that allow us to compare the financial contours of this crisis with earlier episodes. One interesting feature of these data is how they reveal a clear tendency toward financial underdevelopment in the Argentine economy over the long run. Each successive crisis has tended to boost velocity and drive still lower the multiplier as the public fled bank money for cash. (The lone exception was the fall in the multiplier in the hyperinflation of 1988-90, when a flight from pesos to dollars drove M0 down faster than M3.)

Path dependence, embedded in a collective institutional memory, has been one result. As some have described it, after a century or more of money and banking fiascos, Argentines are very wary of putting their assets in peso cash (outside money) or in peso deposits (inside money). Hence, recent measures of money velocity and the money multiplier register little improvement over figures seen a hundred years ago. Even in times devoid of crisis, such as the long postwar interlude from the 1940 s to the 1970 s, were not really times of great success because the techniques used to contain banking crises-policies of financial repression-were also inimical to long run financial development (McKinnon 1973).

Arguably the one episode that had the potential to reverse the trend of financial involution was the second currency board (convertibility) plan of 1991. It did not do so by simply introducing an ultra-hard fixed exchange rate regime - and a failure to grasp this point has been one of the common misunderstandings of Argentina policy during the last decade. The Argentine experiment of the 1990s was harder still, a law that established the principle of dollarized contracts. The law sought to restore credibility to the peso not just by pegging to the dollar but by deliberately and legally embedding financial dollarization throughout the economy-thus raising the economic and political cost still further for any government tempted to countenance devaluation (and, as a consequence, making even a prudent "exit strategy" difficult to devise).

Clearly, then, if the regime was to fail, one could anticipate that it would do so spectacularly. In this respect, it did not disappoint. In the short run, the violation of contracts caused by "pesification" has raised questions about institutions, property rights, and the basic rule of law. Yet even if these cracks are smoothed over, unprecedented problems remain. In past crises at least some strategic decisions were taken to preserve a semblance of reputation in some 
spheres. The long-run budget constraint required someone to bear the pain, so some default was needed, of course. One or two levers could be pulled: maybe to default selectively on debt, either just internally or just externally; or to default on money holdings via inflation; or to temporarily freeze assets and impose forced conversions. This time the authorities have pulled all the levers at the same time. Thus, if we seek bounds on a worst-case scenario, we are afraid to admit that the past may be no guide whatsoever.

However, this would be a brief article indeed if the thrust for presentism were constrained by such gloom. When Bishop, writing in 1890 summed up his article, he noted that radical solutions like foreign financial control were perhaps necessary in a "feeble or decaying state" but that Argentina was not in that position: it was in his view "a vigorous and growing state" where "material wealth exists and is developing." He also believed that Argentina was willing to patiently endure the sacrifice needed to rebuild a tattered reputation, and he quoted a remarkable assertion by President Avellaneda, the leader who guided the country through a crisis in the 1870 s, and who said that "we will suffer thirst and hunger rather than not pay our debts" (Bishop 1891, 538).

Whilst such an outburst would be unlikely from a president today, if a leader could navigate the present crisis as well as his predecessor did the 1890s, there would be much less to fear in the form of economic suffering in the short run. Back then a new commitment to fiscal prudence ensued under Carlos Pellegrini. The Baring Crash had brought down the economically reckless regime of Juárez Celman, yet his vice president was of a different stripe. Through fiscal reforms at home and principled negotiation with creditors abroad, he laid the foundations for a return to stability and growth after the restoration of convertibility in 1899 . He also reformed the banking sector in ways that were to restore stability in the medium term.

Our view of Pellegrini, and one we think future historians will share, is that his management of a debilitating economic crisis was courageous and inspired, and certainly addressed the major problems in a swift and decisive manner. But priorities have to be set, and the political process allows some reforms to proceed faster than others. Pellegrini and subsequent administrations failed in one key respect, leaving an internal-external convertibility weakness at the heart of the Argentine economy that was exposed in 1929. ${ }^{8}$ The same flaw, obscured for many years by the strictures of financial repression at home and isolation from the global economy abroad, has now returned to center stage to be confronted by current or future administrations.

\footnotetext{
${ }^{8}$ That such a flaw should erupt in the 1920s comes as no surprise since many countries other than Argentina had to grapple with similar problems in a shifting political economy situation in the interwar period. At that time, "gold standard rules"-no matter how hard they appeared on paper-proved rather ineffective once the underlying political commitment dissolved or institutional pollution arose, changes that rendered a hard peg much less credible (Obstfeld and Taylor 2003). One might view the dramatic worsening of Argentina's country risk in 2001 under the "dollar exchange standard" in the same light.
} 
Unfortunately for Argentina, the spirit of Gaucho Banking has remained alive and well during the twentieth century, affecting both public and private banks, their relationships with both public and private creditors, and the sustainability of exchange rate regimes. In the rest of this paper we discuss the dynamics of internal and external convertibility and then present a discussion of the 1929 and 2001 crises to illustrate how this problem endured and ultimately brought down two convertibility experiments which for many years had looked nearly indestructible. ${ }^{9}$

\section{Gaucho Banking in Theory and History}

We have argued that a useful model of the internal-external convertibility nexus in the Argentine historical context can be found in an augmented version of the Dornbusch and Frenkel (1984) model, one which includes an allowance for possible "Gaucho Banking" behavior (see della Paolera and Taylor 2002). A theoretical appendix to this paper spells out this model in detail, but we discuss the core element here. The general intuition has much in common with several important advances in the recent theoretical literature that stress the linkages between fixed exchange rates, monetary policy inconsistencies, and banking crises (see, inter alia, Velasco 1987; Chang and Velasco 2000; Burnside et al. 2001).

The dynamic assumptions are a critical part of the model and describe the forces affecting the evolution of inside and outside money under a currency board and a fractional reserve banking system. Regarding inside money, we consider the possibilities of "good" banks and "crony" (Gaucho) banks, where the banking sector, for simplicity, is treated as consolidated. ${ }^{10}$ Good bank policy is driven by a desired reserve-deposit ratio $r^{*}(i)$, where $r^{*}$ is a decreasing function of the (endogenous) interest rate i. Here, better lending opportunities lead the bank to reduce the liquidity of its balance sheet in a prudent way so as to seek profits, but the actual adjustment of $r$ to its target level $r *$ is a partial adjustment process, due to the illiquidity of assets or other adjustment costs, so that

$$
\mathrm{dr} / \mathrm{dt}=\mathrm{v}\left(\mathrm{r}^{*}(\mathrm{i})-\mathrm{r}\right)+\mathrm{v} \phi(\mathrm{r})
$$

\footnotetext{
${ }^{9}$ Our discussion of the 1929 crisis draws on della Paolera and Taylor (2003).

${ }^{10}$ Following Dornbusch and Frenkel (1984), in our model of the 1929 crisis we are ignoring here the role of other private banks. That is, we treat the Banco de la Nación, which already accounted for $50 \%$ of the banking sector by the 1930s, as a proxy for the entire system. However, an alternative view would be to integrate the balance sheets of the Banco de la Nación and the private banks and study the dynamics of the entire system. This is justified, if, as actually happened, the private banks have an implicit insurance guarantee from the state bank. We have repeated our empirical exercise with this aggregation of all the banks and the results were unchanged.
} 
where $\mathrm{r}^{*^{\prime}}<0$ and $v>0$ is an adjustment-speed parameter. The term $\phi(\mathrm{r})$ is assumed to be zero for $\mathrm{r}>\mathrm{r}_{2}>0$.

However, when reserves fall to dangerously low levels $r<r_{2}$ we assume that $\phi(r)$ might be nonzero, and additional lending motives start to operate. We can imagine two possible ways in which the term $\phi(r)$ could operate. The first has $\phi(r)>0, \phi^{\prime}(r)<0$, and $\phi^{\prime \prime}(r)>0$ for $r<r_{2}$; we might call this the conventional "credit crunch" dynamic, since as reserves get precariously low the good bank might tighten credit even more, scrambling to liquidate loans and prop up r. But there is another possibility, with $\phi(r)<0, \phi^{\prime}(r)>0$, and $\phi^{\prime \prime}(r)<0$ for $r<r_{2}$; in this case the bank loosens credit as reserves tumble; this we call the "crony bailout" dynamic, where the bank chooses to sacrifice its own balance sheet to keep others afloat. Why private or public banks should choose to do this, of course, is a political economy problem that we analyze shortly.

Outside money evolution is described by the dynamics of the stock of the reserves of gold (or hard currency), and we assume a rate of gold inflow that is driven by deviations of the (endogenous) local interest rate $\mathrm{i}$ from the world rate $\mathrm{i}^{*} .{ }^{11}$ Thus,

$$
\mathrm{dG} / \mathrm{dt}=\lambda \mathrm{G}\left(\mathrm{i}-\mathrm{i}^{*}+\kappa ; \ldots\right)
$$

where $G_{i}>0$. To enrich the discussion of comparative dynamics we add two new parameters not in our original model: $\lambda$ captures the responsiveness of external capital flows to price signals, and $\kappa$ is the country's risk premium, that is for the present exogenous but could depend on the government's overall fiscal scenario.

This is a very simple myopic model, where agents respond to instantaneous signals and there is no forward-looking behavior. There are no jumping (co-state) variables and the (G,r) variables define a classic deterministic dynamical system. Closure of the model depends on the specification of a function $\mathrm{i}(\mathrm{G}, \mathrm{r})$ to describe money market equilibrium as a function of bank balance sheets and the money base. A standard money-market equilibrium gives the model closure, and need not be repeated here (see the appendix). There are two possible cases, one where $\partial \mathrm{i} / \partial \mathrm{r}>0$ and one where $\partial \mathrm{i} / \partial \mathrm{r}<0$. In the former (normal) case when bank reserves rise, ceteris paribus the money multiplier falls by the direct withdrawal of cash from the market, so the money market tightens. In the latter case, "confidence" effects dominate and when the public sees bank reserves rising their demand for bank deposits (broad money) rises even more, because they feel that banks are safer; thanks to the money multiplier, the switch from cash to deposits expands the money supply, so the money market slackens.

\footnotetext{
${ }^{11}$ That is, we assume gold flows are not (or, at least, not entirely) driven by the trade balance in the manner of David Hume's price-specie-flow mechanism. Indeed, in this short-run model there is no real adjustment. Rather, we appeal to John Stuart Mill's view of an adjustment process driven in large part by capital flows.
} 
Which of these two scenarios prevails has important consequences for the overall dynamic solution of the model and the phase diagram in (G,r)-space. So too does the presence or absence of the crony mechanism captured by the sign of $\phi^{\prime}(r)$. Thus, there are four cases to consider, as shown in Figure 1, and explained in the appendix. The characterization of such local equilibria is simple, but some appeal to intuition is needed to imagine the nature and layout of potential equilibria in a real-world setting. As noted, we think it likely, if not obvious, that the "confidence" effect will dominate at low levels of bank reserves, the kind of situation where depositors get nervous. Also, we claim, the worst cronyism is more likely to erupt in "bad times" in the economy-when bank reserves are low or when gold stocks are low.

With such assumptions in mind, the configuration of the full dynamical system can be displayed once we set out the complete phase diagram in (G,r)-space, as shown in Figure 2. The direction of trajectories is marked in the various regions delineated by the curves $\mathrm{dr} / \mathrm{dt}=0$ and $\mathrm{dG} / \mathrm{dt}=0$. The intersections of the curves are two equilibria, labeled E1 and E2. The point E1, with a high reserve level, corresponds to Figure 1(a) and is a stable node, a "good" equilibrium. The point E2, with a low reserve level, corresponds to Figures 1(c) or (d) and is an unstable saddle point, a "bad" equilibrium. A possible stable saddle path for E2 is shown as SS' and this curve delineates two regions in the plane. Above SS' is a stable zone where all paths lead to the sink at E1. But below $\mathrm{SS}^{\prime}$ is an unstable regime where all paths lead to collapse. ${ }^{12}$

As originally devised, this theoretical framework was ideal for the purpose of studying the dynamics of internal and external convertibility in the Argentine case both before World War One, when the dynamics worked favorably, and in the interwar resumption of 1927-29, when they did not. The key question was: how could a well-defined dynamical system that had once worked so well under the old prewar gold standard then fail so miserably just a few years later? Our model supplies an answer. The evidence suggests to us that during the Argentine Belle Époque prior to World War I, the money and banking system was operating in the stable zone of the phase diagram, in the vicinity of the stable equilibrium E1, with high confidence in the regime sustained by high reserve ratios. The resemblance of the upper right zone of Figure 3 to the stable equilibrium E1 depicted in Figure 2 is striking. The trajectory fluctuated but it did not explode unidirectionally. The gold-standard system was a stable one at the beginning of the century because it was combined with prudent inside-money practices. (VAR analysis confirms this conclusion. See della Paolera and Taylor 2002)

This regime ended in 1914: external shocks and domestic policy choices made gradual, seemingly innocuous changes in the institutional framework. The emergency rediscount

\footnotetext{
${ }^{12}$ Note that this will not generate a crisis in the form of a complete drain of the gold stock-an external convertibility crisis - since the dynamics of $\mathrm{G}$ in the unstable region are such as to take paths away from $\mathrm{G}$ $=0$. Rather, it is a region in which the bank collapses-that is, an internal convertibility crisis is the real threat.
} 
provisions of the Banco de la Nación and the Conversion Office introduced some implicit guarantees into the financial system and increased the scope for moral hazard and abuse. To its credit, the Conversion Office kept its emergency powers in reserve. It was not so at the Banco de la Nación, where rediscounting and nonperforming loans grew steadily after 1914. The pollution of the balance sheet of the Banco de la Nación from 1914 to 1927 is represented in Figure 2 by the line E1-P. Thus, we argue, the system arrived at a point like P by the late 1920s. The dynamical system set to work again during the brief 1927-29 resumption, but this time from new initial conditions at a point like $\mathrm{P}$, with movement along a path like PP'. The trajectory in the lower left zone of Figure 3 reveals a trajectory much like the putative path PP' in Figure 2. Again, the correspondence between the empirical trajectories and the phase diagram is striking. (VAR analysis also confirms this claim. See della Paolera and Taylor 2002)

This is a clean theory that links the demise of the gold standard convertibility regime to the pollution of the Argentine financial system in the 1920s through the persistence of "Gaucho Banking" practices. Yet does theory map into history so cleanly? What additional historical evidence is there to support this notion? We think there is quite a lot, and we summarize it briefly.

From the 1820 s to the 1880 s the multiple banks of issue in Argentina were noted for their exaggerated provision of cheap credit to finance federal and state administrations; in that setting the nominal anchors were very weak. After the Baring crisis in 1890-91, the Pellegrini government designed a new regime. Two institutions were central to the plan and they were kept at arm's length so as effectively to isolate two functions. The note issue, ultimately backed by gold - that is, outside money and external convertibility - was the sole task of the Conversion Office. State and commercial banking activities-that is, inside money and internal convertibility - were the domain of the Banco de la Nación and the rest of the financial system. It was hoped that this separation of powers would constitute a more robust and credible regime by keeping inflationary pressures and banking activity separate from the institution that was ultimately responsible for the currency.

The Banco de la Nación maintained a clean balance sheet at first, as we can see from Figure 4. Then, in the crisis 1913-14 an emergency rediscount law was enacted. Rediscounting surged as a fraction of all banking activity, non-performing loans rose, and the capitalization level of the bank sank. This corrosion of balance sheets was in no way a function of crony lending relations with the government, but rather crony loans to the other banks and the private sector, as we can see from the asset quality indicators in Figure 5. Simple counterfactual liquidity calculations suggest that the Banco de la Nación helped a wounded banking system limp along for many years in the 1920s and 1930s (della Paolera and Taylor 2002). Why? We know the bank did not have an explicit lender-of-last-resort mandate. It was not a true central bank and arrogated 
these powers in an ad hoc fashion. Why was the rediscount law enacted? And why did the bank take on the risks associated with rediscounting to private banks with weak collateral?

It is easy to identify one group that gained from the new policy. The state bank's rediscounting provided a bailout to the private banks once, ex post, it became clear to them that their balance sheets were in a bad state. In essence, the private banks obtained, if not free, then highly subsidized banking insurance from a government that had made no such commitment $e x$ ante. That such an inconsistent policy choice should have been made says a good deal about the machinations inside the Argentine corridors of power. Rich and powerful interests, including officers and shareholders of the banks, desperately needed cover from the risks they had taken, the loans that had gone bad. Some of those same loans, we also know from confidential records, were loans to the very same officers and shareholders, or to their real or shadow corporations.

We see here how Gaucho Banking has been very resilient. Even after the Baring Crash had wiped out most of the Argentine banking system, the spirit of Gaucho Banking lived on into the interwar period. Ultimately, in 1935, as part of a political-economy solution worked out by the government and its new central bank, the banks got the final bailout they sought to head off an insolvency crisis arising from decades of bad loans. It cost about 7\% of GDP and was perhaps the biggest single "Gaucho Banking" action of all time, at least until the present crisis. ${ }^{13}$ One might imagine that after such a disastrous experience, Gaucho Banking would have been laid to rest. But from the years of financial repression of the early postwar period to the opening of the economy in the 1990s, this trait appears to have survived, albeit with a different twist today.

\section{Gaucho Banking Today}

Naturally, a small country such as Argentina, is always vulnerable to foreign shocks-such as the Tequila Effect, the Asian Contagion, the Russian default, and the Brazilian devaluation-yet all of these different shocks were handled perhaps as well as could be expected within a second-best hard-peg regime. However, we claim that while the Argentine outside money mechanism and banking regime were regularly proclaimed as the darlings of the emerging markets, there was always, since the inception of the Convertibility Plan a deep problem in the design of the moneybanking nexus.

By now it is, we hope, widely accepted that the 1990s Convertibility Law was in fact a dollar-exchange standard regime and more. At first, everyone saw its short-run aim as

\footnotetext{
${ }^{13}$ Many of the 1920s rediscounts eventually went bad and would end up on the state balance sheet and the system was evolving toward a central banking idea in a very incoherent manner. It is important to stress that in its rediscounting actions the Banco de la Nación was not engaged in pure lender-of-last-resort actions, like a true central bank following Bagehot's principle of lending freely at a penalty rate. Such actions would have left the bad loans with the private banks whilst extending temporary liquidity. Instead, the state bank lent cash at only 4.5 percent_-far below even the rate offered on time deposits!
} 
establishing a nominal anchor and decisively ending the recurrent use of the inflation tax mechanism but it also respected the choice of agents to basically use the U.S. dollar for large transactions and as the medium to store value and hold wealth. Yet it was not immune to internal weakness and a law that was supposedly robust in its respect for acquired property rights (i.e., a fixed peso-dollar commitment) could not endure in the Argentine political economy nexus.

This flaw was visible even during the earliest crises. During the Tequila crisis, good luck was on the Argentine side because Mexico was bailed out essentially by the United States and the crisis was short-lived. But there too, the potential inconsistency between a dollar-exchange standard and a banking system that "creates" money (even inside dollar money) was brought to the forefront. Curiously enough, few saw that this inconsistency was in the end going to serve as a crucible for the most extraordinary and rapid economic meltdown effect that we have ever seen in any emerging market economy. What also should become clear is that the real disaster began about the time when agents started to feel that even the most basic property rights were being repudiated by the monetary and fiscal authorities.

Thus, there is a crucial difference as compared to the 1929 crisis. Back then it was the rottenness of the private sector that hampered the solvency of the financial sector. In the present episode, the insolvency of the public sector (and the unwillingness, incompetence, weakness, or political fragility of the Alliance government) put in motion a catastrophic dynamic path that polluted the monetary, financial and pension plan system.

So why make a comparison with 1929 ? We will argue that still, in both cases, the transmission mechanisms were the same. In both cases, we are in the presence of a system that can easily jump from a good equilibrium situation to a bad or terminal one, if it is buffeted by a large enough exogenous internal or external shock. And in both cases, the exogenous shocks were internal to Argentina and generated by Gaucho Banking behavior that was unconstrained (indeed, encouraged) by the political economy structure. However, one key difference is that because the Argentine economy was in 2001-02 acutely dollarized, but was not in 1929 "metallized", it was inevitable that today's meltdown process would be much, much faster than in the past. ${ }^{14}$

In Figure 6, we show proxies for the solvency situation of the private and public sectors and it is clear that, even when we know that the activity level was already in a deep slump by 1999, the driving force behind worsening expectations was the solvency of the government and some official banks like the Banco de la Provincia de Buenos Aires. This is exactly what is shown in Figure 7, where there is a "neutral" evolution in the quality of banking assets until, say, January 2000; but then after that the driving force is expected solvency of the government's debt,

\footnotetext{
${ }^{14}$ Economic agents in 1929 had not experienced monetary expansion abuses since 1891, while in 2001 memories of hyperinflation in 1989-90 and persistent inflation taxes since the 1950s were very fresh.
} 
where we must also understand that from April 2001 the banks and pension plan firms were absorbing more and more public bonds.

It is opportune at this stage to recall Figure 2 and its underlying theory, and ask what help the Augmented DF model might be in understanding the dynamics of the 2001 crisis. Unlike 1914-27 there was no suspension of convertibility, in which case-one might ask—how could the dynamical system shift from a stable to an unstable zone? There are several candidate exogenous shocks that could have mattered, or, collectively, might have added to the probability of a transition to explosive behavior by causing the state variables (or initial conditions) to change discontinuously. Consider the following scenarios:

1. Country risk shocks. Due to "news" about underlying fiscal problems there is a sudden increase in country risk $\kappa$. In Figure 2 this corresponds to a need for higher equilibrium domestic interest rates to maintain external equilibrium. This means a leftward shift in the $\mathrm{dG} / \mathrm{dt}=0$ curve, hence a leftward and upward shift in the unstable equilibrium E2 and an upward shift in the saddle path $\mathrm{SS}^{\prime}$. That is, the unstable area on the plane expands. If it expands to include the current (G,r) point, then the system becomes unstable. In fact, a large enough shock to $\kappa$ could lead to a "catastrophe" outcome where the qualitative behavior of the system changes - if the $\mathrm{dG} / \mathrm{dt}=0$ curve moves so far to the left that it no longer intersects the $\mathrm{dr} / \mathrm{dt}=0$ curve then suddenly there are no equilibria at all.

2. "Hotter money" shocks. Due to structural changes in the markets there is a sudden increase in the parameter $\lambda$ (external capital flows become more responsive to prices, as might happen if external borrowing is terminated and "gold flows" must finance all imbalances). This leads the dynamics in the $\mathrm{G}$ dimension to speed up without shifting the location of the equilibria. The effect is to rotate the saddle path $\mathrm{SS}^{\prime}$ about E2 to a flatter position, again expanding the unstable zone.

3. Illiquid asset shocks. Due to structural changes in the markets there is a sudden decrease in the parameter $v$ (banks must adjust their portfolios more slowly, as might happen if a real shock-a recession-leads to more uncallable loans in the short run). This leads the dynamics in the $\mathrm{r}$ dimension to slow down without shifting the location of the equilibria. Again effect is to rotate the saddle path $\mathrm{SS}^{\prime}$ to a flatter position, again expanding the unstable zone.

4. A "bank robbery" shock. There is a one-time "theft" of reserves $r$ from the banks in exchange for debt in a nonmarket (i.e., forced loan) type of transaction. This causes the system to jump in (G,r)-space vertically downwards by the amount of the theft. In 2001 we associate this forced saving with the government's decision to impose the so-called "megaswap" on the financial sector in 2001. (An exogenous shock to the confidence function could also be added here, if agents are moved to suspect additional future robberies, compounding the problem.) 
Of course, it is possible to tell a story of the 2001 crisis using some or all of these elements, and we do not wish to assert a monocausal explanation. All such factors surely contributed, but our reading of history, based on the timing and magnitude of the shocks, leans toward treating the fourth and final mechanism as the most important exogenous force, as we shall argue below. Moreover, we think it is also true that the "megaswap" bank robbery (\#4), via the institutional pollution it engendered, also endogenously changed market reactions via increased country risk (\#1) and even hotter flows of hard currency (\#2). Our narrative henceforth pursues this line of argument.

It should be recalled that this was, all the same, a period with tremendous external shocks and recession that the Argentine system nonetheless withstood. There were signs of increasing health, even. In these years the level of monetization in the economy (the increase in the demand for financial assets within the system) was impressive until 1999 (see Table 1). And the evolution of "voluntary dollarization"- the choice in the denomination of deposits and loans by agents and banks - was stable at a high level of 62 percent. Overall a fairly robust monetary and financial scenario held through 1999: official data show that financial deepening (M3 and deposits relative to GDP) was improving until early 2000 and non-performing loans did not show any major alteration until 2001.

Thus, we share with many the view that the deep force in the crisis was fiscal: robbing the banks was merely a desperate attempt to alleviate that problem. Bad fiscal behavior need not have affected private banks, or international reserves, if the laws passed in 1991 had been respected. But economic agents understood all too well (based on Argentine history, we would argue) that these laws might not be enough to leave secure these parts of the economic system in the renewed presence of intense populist demands that put property rights in peril.

As shown in Figure 8, an ongoing change in the political regime was underway by October 2000, which was concluded in early April with the change in the macroeconomic and central bank policy regime (the return of Cavallo and departure of Pou). From this perspective, April 2001 was the end: the fateful jump from a manageable and still, technocratically speaking, reversible situation to disaster. As in the 1914-27-29 episode, changes in laws (and hence in expectations and/or property rights) produced a jump from a sustainable money-banking nexus to an unsustainable one. The evidence supports this historical parallel. Figure 8 shows that the nexus of international reserves and the reserve-deposit ratio was a stable one for the 1996-99 period. What is very impressive is the speed of adjustment of economic agents to the change in the macroeconomic and central bank regime in April 2001, a change that was arguably foretold with the demise of Economy Minister López Murphy in March. Again, the alteration of the dollarexchange standard and the intervention of the Central Bank in early April 2001 marks a break: from an expectational point of view it was the end of the regime as we knew it from 1991. 
Where then did the weakness of the money-banking nexus originate and how was it obscured for so long? Our main argument is that already within the 1991 Convertibility Law and with a political-economy structure prone to disrespect property rights, the money-banking regime was fragile. And clearly it was fragile basically because the Central Bank of Argentina could not with one instrument attain the two goals of internal and external convertibility: to support the external value of the peso and to shore up an eventual crunch in the (mostly dollar-denominated) monetary liabilities of the system. While the banks were creating "argendollars" the Central Bank could not, of course, print actual dollars. ${ }^{15}$

Economic agents were always well aware of this talon de aquiles of the system-and the only signal they needed to foresee a change in the regime was a populist government putting a tax levy on genuine resources. On that signal they had to run to get their resources out as fast as they could. The period March 2001 to November 2001 was one of "disaster dynamics"-to paraphrase Pou (2002). Even if the dynamics were not exactly monotonic (the August hiatus is explained below) there is a clear path towards crash in Figure 8.

The path was assured when the advance of the government over banks and private pension funds took place with the famous (or infamous) "megaswap" that converted public debt into a 30-year bond but at 16 per cent interest rate. Two thirds of this swap was absorbed by domestic financial institutions. But already in April, with respect to dynamics, many in the public had a suspicion that banks might end up colluding with a government in fiscal freefall. It was then, in early 2001, that there emerged a war of attrition at first between the sophisticated investors and the government-banking axis (Phase 1: April-June) and then between virtually all private agents and government-banking axis (Phase 2: September-November).

The game played out as follows. With the banks aligned to the government objectives, banks realigned their asset side to support the public sector; the private agents, in the meantime, detected the incipient cronyism, and began to realign the banks' liability side. The banks started to recoup credits from the private sector, and the lending rate (30-days dollar) for AAA corporate debt rose in eight months from $13 \%$ in February to $27 \%$ in October 2001. At the same time lending to the public sector jumped from one third of total lending to almost a half by the end of 2001 (see Table2). Thus the private sector was crowded out and the banks became polluted.

To make things more dramatic, the public's "voluntary dollarization" increased from a stable two-thirds level in terms of loans and deposits (where it had been for many years) to almost 75 per cent just before the implementation of the bank deposit freeze (corralito). The private agents thus tried to hedge more and more against a domestic institution and adopted more dollar

\footnotetext{
${ }^{15}$ An opportunity to change this state of affairs was clearly present after the warning events of the Tequila crisis but the solution, which was then deemed satisfactory, was simply the negotiation of a substantial contingent credit line with international organizations. In the end, this proved inadequate to the task.
} 
denominated assets. Hence, even when uncertainty was paramount, the economic agents and the authorities (intentionally or not) were enhancing dollarization. At this point, the war of attrition was at its culminating moment. Either the system would break in favor of a discretionary softbudget monetary regime, or there was going to be (total) dollarization and a substantial adjustment in the cash flow in dollars of public (national and provincial) finances.

There was one faint hope for the depositors. At some point, the public had believed that the internationalization of the banks would play a role at a crucial hour in forcing a respect for the rules of the game. Perhaps they also believed that external discipline from the IMF would also protect the rule of law against abuses. Yet IMF help continued to arrive even after Argentina was on the slippery slope with another loan tranche disbursed in August 2001, an action for which the Fund has been extensively criticized elsewhere (e.g., Mussa 2002). We need not rehash these criticisms here, but the final loan explains the August jump in international reserves (seen in Figure 8), replenished by the IMF funds-but of course there was no change in fundamental policy measures, and from the public's perspective the government's prior abuse of property rights in April and May appeared to be tolerated, if not vindicated.

With the arrival of the crisis seemingly unconstrained Gaucho Banking tendencies emerged. By late 2001 the policy framework can only be described as one of chaotic desperation. In the last two months fiscal and debt measures became chaotic and inchoate, and central-banking resolutions accelerated dollarization. Some Argentines held on to the conviction that it would be more complicated for the government to sack their assets if they were in a foreign bank and if they were in genuinely dollar-denominated assets—but in the end not even these obstacles stood in the way of the corralito in December and the pesification in January 2002.

\section{The Political Economy of Gaucho Banking in 2001}

Why do we characterize the behavior of banks as Gaucho Banking? In other words, is this a fair description of what happened in the year 2001 in Argentina? Were banks coerced or did they collude with political forces? And what pressures drove the political operators into such schemes?

The first fact is that banks colluded in the first half of 2001 with the Argentine Republic's government. Our interpretation is that during this brief period bank behavior bore the legacy of past recurrent bailouts in not-so-distant Argentine financial history. The records of the 1981, 1985, and 1989/1990 bailout episodes, carried out under the auspices of the 1977 Banking Law, were still fresh in the minds of agents and bankers alike. The presence of a radically different monetary regime, the dollar-exchange standard, was surely underestimated and did not prevent bankers from engaging in a risky play of trying to temporarily "bail out" the government. The initial switch by banks in April 2001 and May 2002 towards investing in high-yield sovereign bonds was the start of an extremely risky policy—one that we think can be transparently seen as a 
collusive outcome between most banks and the government. The implicit agreement was simple: you help me now and I will help you in the immediate future.

These dangerous liaisons are well recognized we think, as in de la Torre, Levy Yeyati and Schmukler (this volume, quote from the draft version):

Instead of recognizing that debt restructuring was becoming a necessity following the failed attempts to restore growth, the government averted debt service arrears by draining the liquidity of the financial system. In April 2001, the government used moral suasion to place U\$S 2 billion of bonds with banks in Argentina, allowing banks to use those bonds to meet up to 18 percent of the liquidity requirement. The banking system thus became substantially less liquid and much more exposed to a government default... As choices to finance the deficit through debt rapidly shrank, the specter of money printing loomed bigger... (emphasis added)

Moral suasion, which is far weaker than coercion, could have been resisted by the banks. But it was not. In other words, to an extent that was unknown under the Convertibility Plan, fiscal needs and the monetary base were again firmly intertwined from April 2001. This is where the pollution of the entire regime began.

We know that banks were also subject to moral suasion to take the "megaswap" in the summer and by then, we believe, they were quite convinced that if the high returns did not materialize they would be (somehow) bailed out by the government. It is beyond the scope of this paper to speculate as to ex ante where they thought these resources would come from-and if this would involve pesification. By the end, however, they surely saw pesification as a potential answer (see Velasco and Hausmann, this volume) if the scheme was to fail. Our approach suggests one way to understand how it did fail: the government and the banks neglected to include in their calculation an even more intelligent group of agents, the public. If the banking sector is weakened "disaster dynamics" can take over as the "war" between the agents and the state unwinds. We have documented this progression for Argentina from early 2001.

However, in addition to the direct relationship between the private banks and the state, we argue that the central government was engaged in a war on another front-with the provincial governments (and their own banks), especially the large and opposition-controlled Province of Buenos Aires. The fiscal "war of attrition" is an old idea, but a new twist in the Argentine crisis was the expansion of battlefield. Specifically, provincial policies turned the Banco de la Provincia de Buenos Aires into a very large bomb. This had important consequences for the implosion of the banking sector and reveals a severe political economy constraint in a caudillo world. 
Looking back at Figure 6 we can see that the national government was not the sole bank robber. It is striking that the behavior of the Banco de la Provincia de Buenos Aires is singularly characterized by a massive explosion in crony lending as judged by the evolution of nonperforming loans for the year 2000. The differential behavior between the Banco de la Nacion Argentina, controlled by the national government, and the Banco de la Provincia de Buenos Aires (BPBA), controlled by the duhaldismo wing of the Peronist party, hints that already, starting in 2000 , there was an emerging fiscal war of attrition between the government and the most important Argentine province controlled by the opposition. Moreover, this war was not merely to be contested on the usual battlefield of receipts, taxes, and the fight over provincial revenue sharing under the federal compact. Rather, by extracting resources from its state bank, the BPBA, the new offensive had implications for the larger financial system, and begged questions as to the national government's lender of last resort capability.

This game, its political economy, and its conduit through the BPBA, has been neglected but is highly relevant for our understanding of the larger fiscal crisis, its transmission in part from the provincial to the federal level, and its infection of the banking system. The game unfolded as a contest between a national government that, initially, was desperately sticking to the established rules of the game, and the opposing forces of duhaldismo and the traditional political class, which could only survive if soft money was provided on a continuous basis. It need hardly be said that for most of the 1991-98 period, the soft money conduit had not been threatened: the national government had been in Peronist hands, the economy had been booming its way out of a long slump, and fiscal largesse had been accommodated, thanks to the leeway provided by a highly liquid international capital market. Fiscal problems were present (e.g. the country ran persistent public-sector deficits even during boom times); but, to most, they were not very apparent. When international liquidity ebbed, the war of fiscal attrition broke out in the banking and the monetary arena with the printing of provincial quasi-monies, in particular, the patacones.

Thus, in the fiscal arena, the Convertibility Law forced the question for the nation and the provinces. The pretense of provincial governments was that they could use provincial and state banks just as the national government was using the financial system and the liquidity of convertible pesos for fiscal needs-and that all quasi-monies would always be accepted at par with the Argentine convertible peso. Convertibility and a sound banking system were essentially at odds with the old political economy status quo: hence pesification was the populist course of action that loomed closer for almost a year, gathering support at home and abroad.

Ironically, although some of the worst fiscal leakages originated from the bonaerense authorities, after a few more moves in the endgame the provincial leader was eventually installed as the President of the Republic just as pesification was implemented. During the wars of Argentine succession, reports were rife that duhaldismo usurped power through a crude power 
struggle on the street; but in many ways the key fighting had taken place much earlier-not on the streets but on the books. Leading the fiscal war with other provinces and running down the assets of the BPBA was a major part of the economic coup d'état that ended the convertible regime and de la Rua's authority. The change of presidents was then something of a coup de grace that put the convertibility plan out of its misery, allowing space for default, pesification, property rights adaptation, Gaucho Banking and the like.

\section{Lessons from the Past and Present}

The purpose of this paper was to compare two crises in more detail, with the hope that the lessons of two failed convertibility plans can inspire better performance in the future. The two crises of 1929 and 2001 exhibit many similarities in their dynamics but important differences in their root causes. Undoubtedly, the monetary regime was a striking common factor in both cases. Under a gold standard (or dollar standard) regime, adjustments in the money-banking nexus need to be decisive and fast. Attempts to use monetary and banking institutions in a discretionary way to "lean against the wind" can backfire once the (very tight) limits on room for maneuver are reached. ${ }^{16}$

This is not news to Argentines. Alec Ford's vision was of a gold standard that amplified economic cycles:

It is easy to understand the dislike of some Argentines for a system which dictated that a slump must be aggravated by monetary reactions, although, doubtless, they had forgotten that the same system served to enhance booms. (Ford 1962, p. 188).

Silvio Gesell held a similar view:

Our money is so intimately and solidly linked to gold, as the pound sterling is and even more so than the franc and the mark... If, in some faroff country with a gold standard, a crisis develops, this crisis will have immediate repercussions for the Argentine paper currency.... And it should be that way, as that is what the Law of Conversion is all about. He that enjoys the advantages of an international money must also accept its inconveniences, the pros and the cons of monetary solidarity. (Gesell 1909, p. 56).

One cannot be in any doubt that policymakers, in Buenos Aires or in Washington, knew that this was the price to be paid for the chosen anchor. In light of this, policymakers will again have to question whether they really can tolerate the limits imposed on them by ultra-hard pegs, especially when the institutional superstructure of their economies is not as highly developed as their ambitions.

\footnotetext{
${ }^{16}$ This is not to say there is zero "room for maneuver" under hard pegs- just, relatively speaking, not very much (see Frankel, Serven and Schmukler 2002; and Obstfeld, Taylor, and Shambaugh 2002).
} 
Hard pegs and open capital markets can expose soft money and banking regimes to harsh tests. This is an unavoidable implication of the trilemma. There can be no lender of last resort and almost no monetary activism is possible except within tightly prescribed limits. And there can be almost no policy independence whatsoever if fiscal options are closed off by a debt ceiling, the situation in Argentina in 2001. Paradoxically, when the options are most limited, we think history shows that this is can be where the going may get very dangerous indeed. Policymakers can then be tempted by desperate measures: printing money or, what is in some ways the same thing, and arguably more forthright, actually robbing the banks.

The collapse of the first convertibility plan in 1929 can be traced to changes in money and banking laws of 1914. But this set in motion a very slow train wreck-because convertibility was suspended until 1927, and only then was the instability exposed. Moreover, demand for money in peso form was still almost universal. The collapse of second convertibility plan in 2001 was also due to changes in money and banking regime. This was a fast train wreck because there was no suspension, dollarization was already very high, and because the institutional changes were so large. Yet the main thing to note, we think, is that in 1929 asset pollution originated in private sector (with bank complicity) but in 2001 it originated in public sector (with bank complicity). Either way, the cronyism of banks was a crucial factor in encouraging the destruction of seemingly robust monetary and financial institutions.

We agree with many observers that the root problem in 2001 was fiscal, and our paper merely suggests ways in which fiscal problems can be more or less dangerous depending on the ways in which their collateral damage is (or is not) contained by clean institutions. As we have noted, at the end of the day, if the long run budget constraint is to hold and fiscal conditions are unsustainable then the authorities have to default on something. Perhaps the most pressing question is why the situation could not have been allowed to proceed via a simple and orderly default process, if indeed fiscal sustainability was the problem, since at least that might have avoided the collapse of the entire money and banking system too. The failure to navigate to such a position turned a serious, but technically manageable, default into a complete and utter meltdown of the economy and its institutions.

What are the alternatives? More research is needed, but assuming one is living in a Gaucho Banking world, more serious consideration could be given to an alternative second best monetary regime: dollarization, plus a more robust separation between outside money and inside money than was seen in either the 1920s or the 1990s-a policy, perhaps, of narrow banking. Good property rights in money and banking can coexist even with a rotten fiscal regime. The latter means that the economy is going to be fragile, but in a more safe second best situation. Under dollarization and narrow banking you will not have to suffer potentially catastrophic leaks from the fiscal side to the monetary and banking nexus. Separating outside money from inside 
money will not cure the problem of excess voracity in the fiscal domain, but one advantage would be that economic agents would feel an immediate effect through the pricing of their assets in banks if the balance sheets of the banks were polluted by fiscal spillovers. In other words, you would know more transparently if your bank was being robbed. The value of deposits might be volatile, but a terminal state in which the losses are ex post socialized would be avoided. The corralito and pesification solutions might then be avoided.

Another policy that might implement more constraints on Gaucho activity would be free pricing of provincial debt, which also formed a large and increasing share of bank assets in 2001, including the notorious quasi-monies such as the patacones. The provinces were (and still are) another polluting factor in the accelerating fiscal implosion, but this reflected in part their remarkable ability to float the bearer bonds. But this was only because the Argentine government in 2001, instead of accepting the provincial monies as fiscal receipts at a market (discounted) value, allowed the payment of taxes with those provincial monies at par. To state it baldly: by unifying the federal and provincial balance sheets with this decree, and effectively permitting all the provinces to this print unlimited pesos, the convertibility plan was technically over. The act of taking control of the note issue away from the Central Bank was remarkable-not only in that it turned the clock back to the 1880 s, but also because of the notable lack of dissent this plan generated. In the face of an unwillingness on the part of the provinces to adjust, the better solution would have been to impose on the provinces a market discipline for their debt issue via a floating exchange rate for their quasi-monies, while still being able to preserve a convertible regime (even short of dollarizing) at the national level.

What next? Progress will be slow. A new political class could address the crony functions of the banks, especially the quasi-public banks, to remove the serious corruption problem from the money and banking regime. As in the 1890s this might mean the wholesale closure of the crony banks themselves, which happened back then under keen pressure from London (Illustration 1). Even then, it did not eradicate the problem forever. To take such a step now would be a very radical plan. However, it might be the only way to end Gaucho Banking and deliver a clean money-banking nexus in an institutionally weak economy, though it is quite hard to see this happening without strong external pressure, for example, through IMF conditionality. Robbing the banks was the only means for the old political class to survive—if only briefly — by socializing the losses, but it has left a burden on future generations that is immensely high.

Our brief tour of Argentine history convinces us that the Gaucho Banking problem identified by Lawson more than a century ago still remains to be solved. Without some fundamental changes to its monetary-fiscal-banking architecture, Argentina will experience instability problems for decades to come. To recapitulate, Gaucho Banking is a scenario where either the public or the private sector through complicity with the banks imposes a capital levy (a 
grab from depositors). Knowing the perils of time-inconsistent behavior, no developed country today would countenance such expedients. There may be other problems in designing banking policies, but if anything they revolve around the reverse fear, worries over a "negative capital levy" (a gift to depositors) arising from bailouts via moral hazard. But for Argentina in 2001 the concern was that of a more ancien regime: to use the banks as a fiscal source for a government bailout. Welcome to the Willie Sutton School of Public Policy: when modern economic orthodoxy collides with caudillo-style institutional backwardness and leadership complicity, a desperate regime with its hands tied in both monetary and fiscal domains will be sorely tempted by a "capital levy" on the financial sector because, as the man said when asked why he robbed banks, "that's where the money is." Unfortunately, that money doesn't last forever. 


\section{Theoretical Appendix}

The model focuses on two major financial entities. The Conversion Office has a balance sheet that consists of liabilities in the form of circulating notes $\mathrm{H}$ (high-powered money or monetary base), and assets comprised of gold $\mathrm{G}$ and securities $\mathrm{S}$. By assumption, $\mathrm{H}=\mathrm{G}+\mathrm{S}$. The banking sector (the public Banco de la Nación and others), treated here as a representative bank, has a balance sheet with liabilities comprised of banking deposits both private $\mathrm{D}$ and public $\mathrm{D}^{\prime}$, and assets in the form of note reserves $\mathrm{R}$ (vault cash) and loans L. Here, $\mathrm{R}+\mathrm{L}=\mathrm{D}+\mathrm{D}^{\prime}$.

The demand for broad money is assumed to be standard, given by $M=m(c, r)(G+S)$, where $\mathrm{m}(\mathrm{c}, \mathrm{r})=(1+\mathrm{c}) /(\mathrm{c}+\mathrm{r} \alpha)$ is the money multiplier, $\alpha=\left(\mathrm{D}+\mathrm{D}^{\prime}\right) / \mathrm{D}$ is the ratio of total to private deposits, $r=R /\left(D+D^{\prime}\right)$ is the reserve-to-total-deposit ratio of the bank, and $c=(H-R) / D$ is the currency-to-privatedeposit ratio of the (non-bank) public. Clearly, $\partial \mathrm{m} / \partial \mathrm{r}<0$ and we can also assume that $\partial \mathrm{m} / \partial \mathrm{c}<0$, since $\mathrm{r} \alpha<1$ in the empirically relevant range. The currency-to-private-deposit ratio $\mathrm{c}$ desired by the public is assumed to depend on how banks behave. A higher reserve ratio at the bank inspires confidence and leads to a lower demand for currency, so that $c=c(r)$, where $c^{\prime}<0$. Given the public's choice of $c$, we can then write broad money $M$ as $M=\mu(r)(G+S)$, where $\mu(r)=m(c(r), r)$.

An important feature is that the relationship of the multiplier to the reserve-to-total-deposit ratio $r$ is ambiguous and the cases $\mu^{\prime}(r)<0$ and $\mu^{\prime}(r)>0$ are both possible. We argue for an intuitive mapping between this derivative and the reserve level. In the usual case, when bank reserves $r>r_{1}$ are adequate, we shall assume that $\mu(r)^{\prime}<0$, so that confidence effects, operating via $c(r)$, are not dominant. But when bank reserves $r<r_{1}$ are sufficiently small we shall assume that the public gets nervous, their currency holdings react more acutely to the reserve level, $\mu^{\prime}(r)>0$, and confidence effects dominate.

Money-market equilibrium will generate an equilibrium interest rate such that $\mu(\mathrm{r})(\mathrm{G}+\mathrm{S})=\mathrm{L}(\mathrm{i}, \mathrm{y})$, where $\mathrm{L}_{\mathrm{i}}<0, \mathrm{~L}_{\mathrm{y}}>0$. The model is purely a short-run model of crisis so it is assumed that output y remains exogenous in the short run. We invert and solve for the interest rate $\mathrm{i}=\mathrm{i}(\mathrm{r}, \mathrm{G} ; \ldots)$ using the implicit function theorem. Clearly, $\mathrm{i}_{\mathrm{G}}<0$; but the sign of $\mathrm{i}_{\mathrm{r}}$ is ambiguous, of the opposite sign to $\mu^{\prime}(\mathrm{r})$, and the latter is ambiguous because of the confidence problem. Dynamics complete the model as described in the main text.

As we show in della Paolera and Taylor (2002) this dynamical system admits four types of equilibria, described as follows and shown in Figure 1. The first is the standard solution given by Dornbusch and Frenkel (1984):

1. Normal Conditions-High Reserves and a Stable Equilibrium: Assume that reserve ratios $\mathrm{r}>$ $\mathrm{r}_{0}=\max \left(\mathrm{r}_{1}, \mathrm{r}_{2}\right)$ are sufficiently high. There is "confidence": an increase in the reserve-deposit ratio by the bank tightens the money market, and lures the public back into holding money balances. For the bank, nothing besides profit motives affect leverage choice and $\phi(r)=0$.

Other solutions obtain under conditions of financial fragility and generate potentially unstable equilibria. If reserve ratios $r<r_{0}$ are sufficiently low there are three destabilizing possibilities:

2. Confidence Problems and Weak or Absent Cronyism: Under these conditions, there are confidence problems. For the public this means that the money multiplier is an increasing function of reserves, $\mu^{\prime}(r)>0$, and hence $i_{r}<0$. For the bank, under low reserves either a "credit crunch" operates, $\phi^{\prime}(r)<0$, or, at worst, a weak crony effect, $\phi^{\prime}(r)<1$. The steady state is a focus, stable or unstable depending on the parameter values. (Note that without the addition of the "crony bailout" mechanism, or some other forces, the unstable saddle-point equilibrium described by Dornbusch and Frenkel (1984, 258-59) cannot exist.)

3. Large Crony Problem and No Confidence Problems: As in the stable case, there are no "confidence" problems, so $\mu(r)<0$, and hence $i_{r}>0$. For the bank, the "crony bailout" forces operate and $\phi^{\prime}(\mathrm{r})>0$. We assume now that this crony effect is sufficiently large, $\phi^{\prime}(\mathrm{r})>1$. The steady state is a saddle point.

4. Confidence Problems and Large Crony Problems: Here both of the abnormal forces operate. Confidence problems imply $\mu(\mathrm{r})>0$, and hence $\mathrm{i}_{\mathrm{r}}<0$. A large crony effect has $\phi^{\prime}(\mathrm{r})>1$. The arrows show that again the steady state is a saddle point.

In della Paolera and Taylor (2002) we argue that cases 3 or 4 are the appropriate model for the 1920s. Conversely, we see case 1 as the likely characterization of the 1900-14 golden age. 


\section{References}

Bishop, W. H. The Argentine Crisis. 1891. Economic Journal 1 (3): 533-38.

Burnside, Craig, Martin S. Eichenbaum, and Sergio Rebelo. 2001. Government Guarantees and Selffulfilling Speculative Attacks. Photocopy.

Chang, Roberto, and Andrés Velasco. 2000. Liquidity Crises in Emerging Markets: Theory and Policy. In NBER Macroeconomics Annual 1999, edited by B. S. Bernanke and K. Rogoff.

della Paolera, Gerardo, and Alan M. Taylor. 2001. Straining at the Anchor: The Argentine Currency Board and the Search for Macroeconomic Stability, 1880-1935, NBER Series on Long-Term Factors in Economic Growth. Chicago: University of Chicago Press.

della Paolera, Gerardo, and Alan M. Taylor. 2002. Internal Versus External Convertibility and EmergingMarket Crises: Lessons from Argentine History. Explorations in Economic History 39 (4): $357-89$.

Dornbusch, Rudiger, and Jacob A. Frenkel. 1984. The Gold Standard and the Bank of England in the Crisis of 1847. In A Retrospective on the Classical Gold Standard, 1821-1931, edited by M. D. Bordo and A. J. Schwartz. Chicago: University of Chicago Press.

Ford, Alec G. 1962. The Gold Standard, 1880-1914: Britain and Argentina. Oxford: Clarendon Press.

Frankel, Jeffrey A., Sergio L. Schmukler, and Luis Servén. 2002. Global Transmission of Interest Rates: Monetary Independence and Currency Regime. Working Paper Series no. 8828, National Bureau of Economic Research (March).

Gesell, Silvio. 1898 [1909]. La anemia monetaria. In n.t. Buenos Aires.

Gesell, Silvio. 1909. La pletora monetaria. In n.t. Buenos Aires.

Hausmann, Ricardo. 2001. A Way Out for Argentina: The Currency Board Cannot Survive Much Longer. Financial Times, October 30.

Kaminsky, Graciela L., and Carmen M. Reinhart. 1999. The Twin Crises: The Causes of Banking and Balance-of-Payments Problems. American Economic Review 89 (3): 473-500.

Krugman, Paul. 1979. A Model of Balance of Payments Crises. Journal of Money, Credit and Banking 11 (3): 311-325.

McKinnon, Ronald I. 1973. Money and Capital in Economic Development. Washington, D.C.: The Brookings Institution.

Mussa, Michael. 2002. Argentina and the Fund: From Triumph to Tragedy. Washington, D.C.: Institute for International Economics.

Obstfeld, Maurice, and Alan M. Taylor. 2003. Sovereign Risk, Credibility, and the Gold Standard: 1870-1913 versus 1925-31. Economic Journal. Forthcoming.

Obstfeld, Maurice, Jay C. Shambaugh, and Alan M. Taylor. 2002. The Trilemma in History: Policy Choices for Exchange Rates, Monetary Policies, and Capital Mobility. University of California, Berkeley (August). Photocopy.

Pou, Pedro. 2002. Comments at the NBER Conference on The Argentina Crisis, July 17, Cambridge, Mass.

Reinhart, Carmen M., and Kenneth S. Rogoff. 2002. The Modern History of Exchange Rate Arrangements: A Reinterpretation. Working Paper Series no. 8963, National Bureau of Economic Research (May).

Velasco, Andrés. 1987. Financial and Balance-of-Payments Crises. Journal of Development Economics 27: $263-83$. 
TABLE 1

MONETARY AND BANKING REGIMES AND MAJOR CRISES, 1890-2001

\begin{tabular}{|c|c|c|c|c|c|c|c|c|}
\hline & Monetary regime & Banking regime & $\begin{array}{c}\text { Previous peak to } \\
\text { trough fall in real } \\
\text { GDP }\end{array}$ & $\begin{array}{l}\text { Years to } \\
\text { regain } \\
\text { previous } \\
\text { peak }\end{array}$ & $\begin{array}{c}\text { Devaluation } \\
\text { (years 1-2) }\end{array}$ & $\begin{array}{l}\text { Inflation } \\
\text { (years 1-2) }\end{array}$ & $\begin{array}{c}\text { [Min,max] } \\
\text { velocity* } \\
\text { GDP/M3 }\end{array}$ & $\begin{array}{c}\text { [Max,Min] } \\
\text { multiplier* } \\
\text { M3/M0 }\end{array}$ \\
\hline 1890-91 & Dirty float & Law of national guaranteed banks & $15 \%$ & 5 & $108 \%$ & $119 \%$ & {$[1.4,3.7]$} & {$[3.1,1.3]$} \\
\hline 1913-14 & Gold standard (currency board) & Commercial code & $20 \%$ & 7 & $-3 \%$ & $21 \%$ & {$[2.4,2.6]$} & {$[2.2,1.8]$} \\
\hline 1929-31 & Gold standard (currency board) & Commercial code & $14 \%$ & 6 & $45 \%$ & $-8 \%$ & {$[1.9,2.4]$} & {$[3.7,2.4]$} \\
\hline 1980-81 & Dirty float (crawling peg) & Law of 1977 & $10 \%$ & 7 & $\sim 2000 \%$ & $\sim 750 \%$ & {$[3.8,5.7]$} & {$[4.0,1.1]$} \\
\hline 1988-90 & Dirty float (crawling peg) & Law of 1977 & $8 \%$ & 4 & $\sim 60000 \%$ & $\sim 50000 \%$ & {$[3.4,12.8]$} & {$[1.8,1.3] \S$} \\
\hline 1994-95 & Dollar standard (currency board) & Law of 1977 & $3 \%$ & 2 & $0 \%$ & $0 \%$ & {$[4.8,5.4]$} & {$[3.5,2.7]$} \\
\hline $2001-02$ & Dollar standard (currency board) & Law of 1977 & $\geq 22 \%$ ? & $\geq 8$ ? & $>260 \%$ & $>40 \%$ & {$[2.9,3.4] \dagger$} & {$[4.0,3.0] \dagger$} \\
\hline
\end{tabular}

$*$ M3 and M0 in pesos only, excluding dollar cash and accounts. $\dagger$ Up to the bank freeze, December 2001. §The multiplier rose during the hyperinflation.

Sources: From della Paolera and Taylor (2003) statistical appendix, except 1994-95 and 2001-02 ratios from Central Bank and Finance Ministry data. The other figures from 2001-02 are based on a GDP peak in 1998 and "?" indicates they are purely speculative based on conditions at the time of writing. The 22\% peakto-trough figure in the last row is based on the reported 9\% fall in real GDP from 1998 to 2001, and the latest 13\% year-to-year fall reported for 2001-02 (Q2), with both figures taken from Informe Económico Trimestral online at http://www.mecon.ar. This is a lower bound on the overall peak-to-trough fall. The 8 year figure for recovery of previous peak is based on an upper bound guess of $5 \%$ growth per annum over the next four years.

TABLE 2

MONETARY AND BANKING EVOLUTION 1995-2001

\begin{tabular}{|c|c|c|c|c|c|c|c|}
\hline & \multicolumn{4}{|c|}{ Financial Fragility } & \multicolumn{2}{|c|}{ Evolution of Dollarization } & \multirow{2}{*}{$\begin{array}{l}\text { "Crowding Out" } \\
\text { Ratio of public credit } \\
\text { to total credit }\end{array}$} \\
\hline & $\mathrm{M} 3 / \mathrm{M} 0$ & M0/Reserves & M3/International Reserves & Change in Deposits $(\%)^{*}$ & $\mathrm{D} * /(\mathrm{D}+\mathrm{D} *)$ & $\mathrm{L} * /(\mathrm{L}+\mathrm{L} *)$ & \\
\hline 1995 & 3.9 & 0.94 & 3.7 & - & 0.57 & 0.58 & $32 \%$ \\
\hline 1996 & 3.9 & 1.03 & 4.0 & 19.5 & 0.58 & 0.60 & $33 \%$ \\
\hline 1997 & 3.7 & 1.04 & 3.8 & 21.9 & 0.56 & 0.61 & $31 \%$ \\
\hline 1998 & 4.2 & 0.88 & 3.7 & 11.8 & 0.58 & 0.62 & $30 \%$ \\
\hline 1999 & 4.2 & 0.89 & 3.7 & 2.3 & 0.62 & 0.62 & $33 \%$ \\
\hline 2000 & 4.5 & 0.90 & 4.0 & 3.3 & 0.65 & 0.62 & $35 \%$ \\
\hline 2001 & 6.9 & 0.78 & 5.4 & -17.7 & 0.74 & 0.71 & $47 \%$ \\
\hline
\end{tabular}

Sources: Central Bank and Finance Ministry data. 
Figure 1

Equilibria in the Augmented Dornbusch-Frenkel Model

(a) Stable Case with Confidence

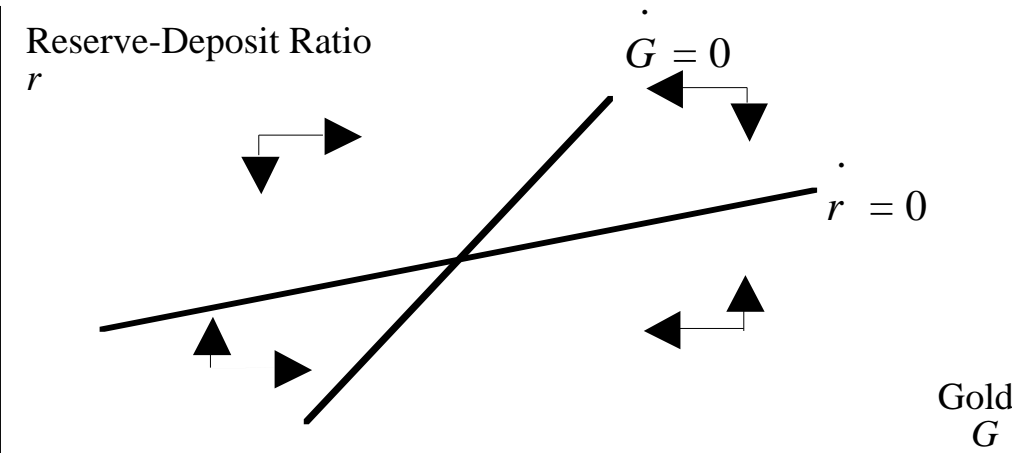

(c) Large Crony Effect Only

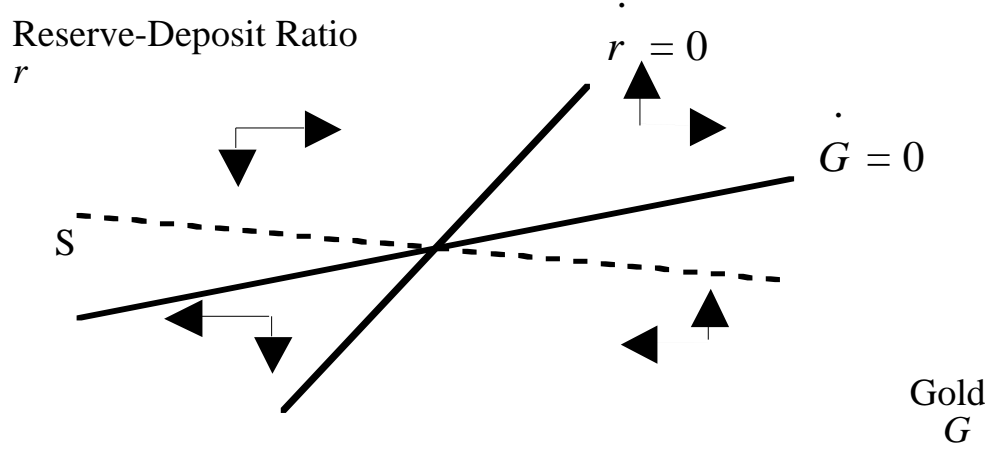

(b) Confidence Problem with Credit Crunch or Weak Crony Effect

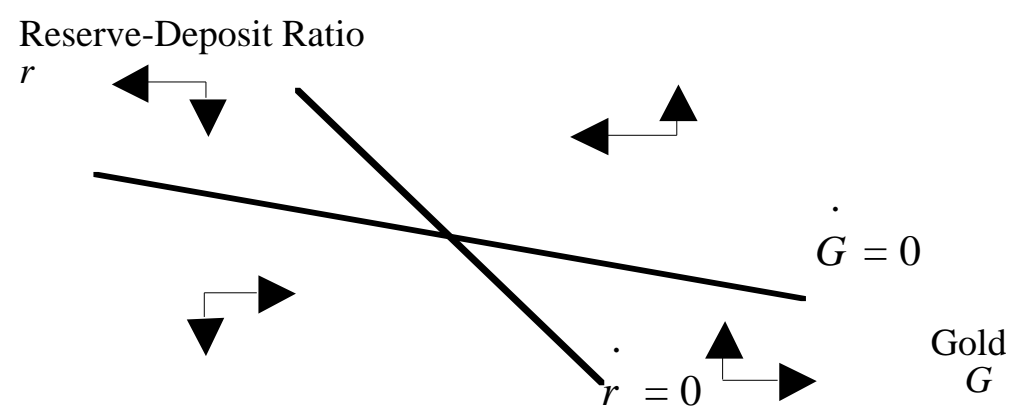

(d) Confidence Problem with Large Crony Effect

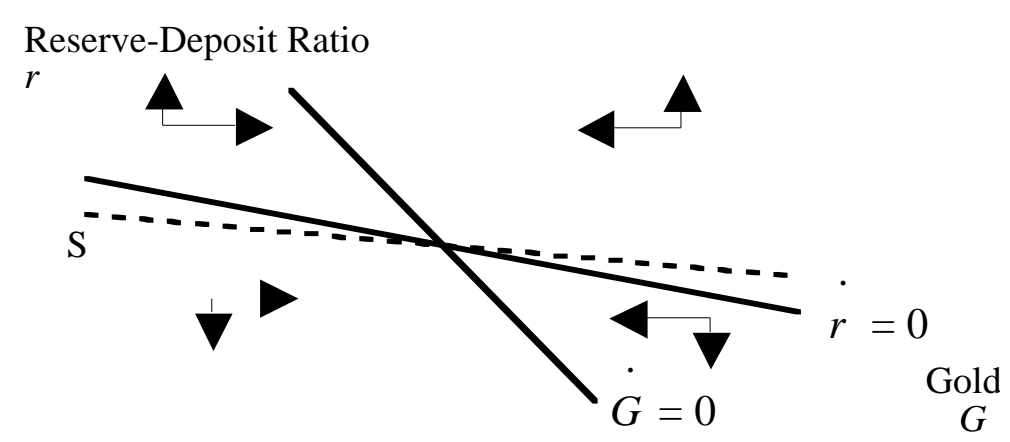


Figure 2

Phase Diagram for Prewar and Interwar Argentina

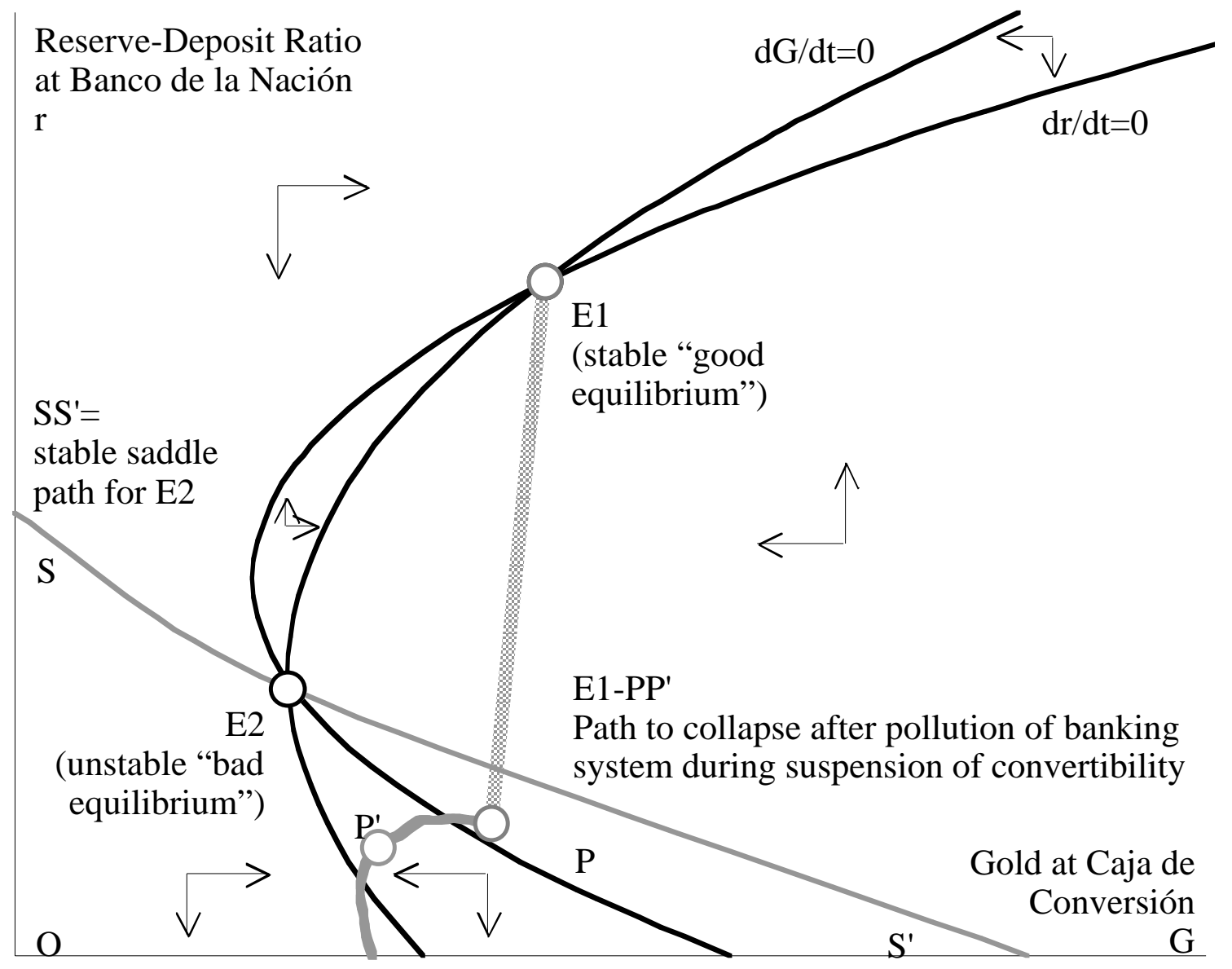


Figure 3

Data for 1908-14 and 1927-29

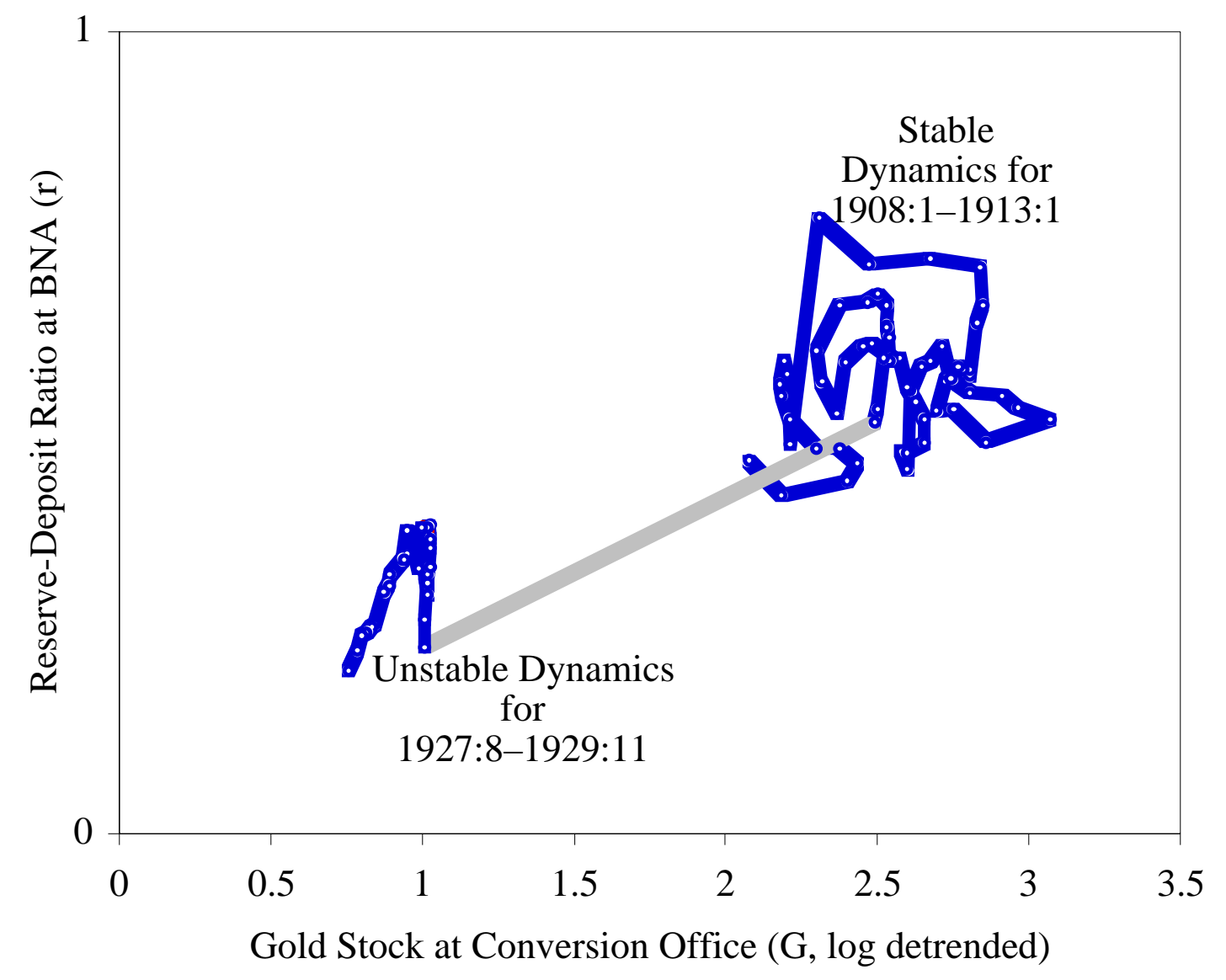


Figure 4

Pollution of the Banco de la Nación Balance Sheet, 1890s-1930s

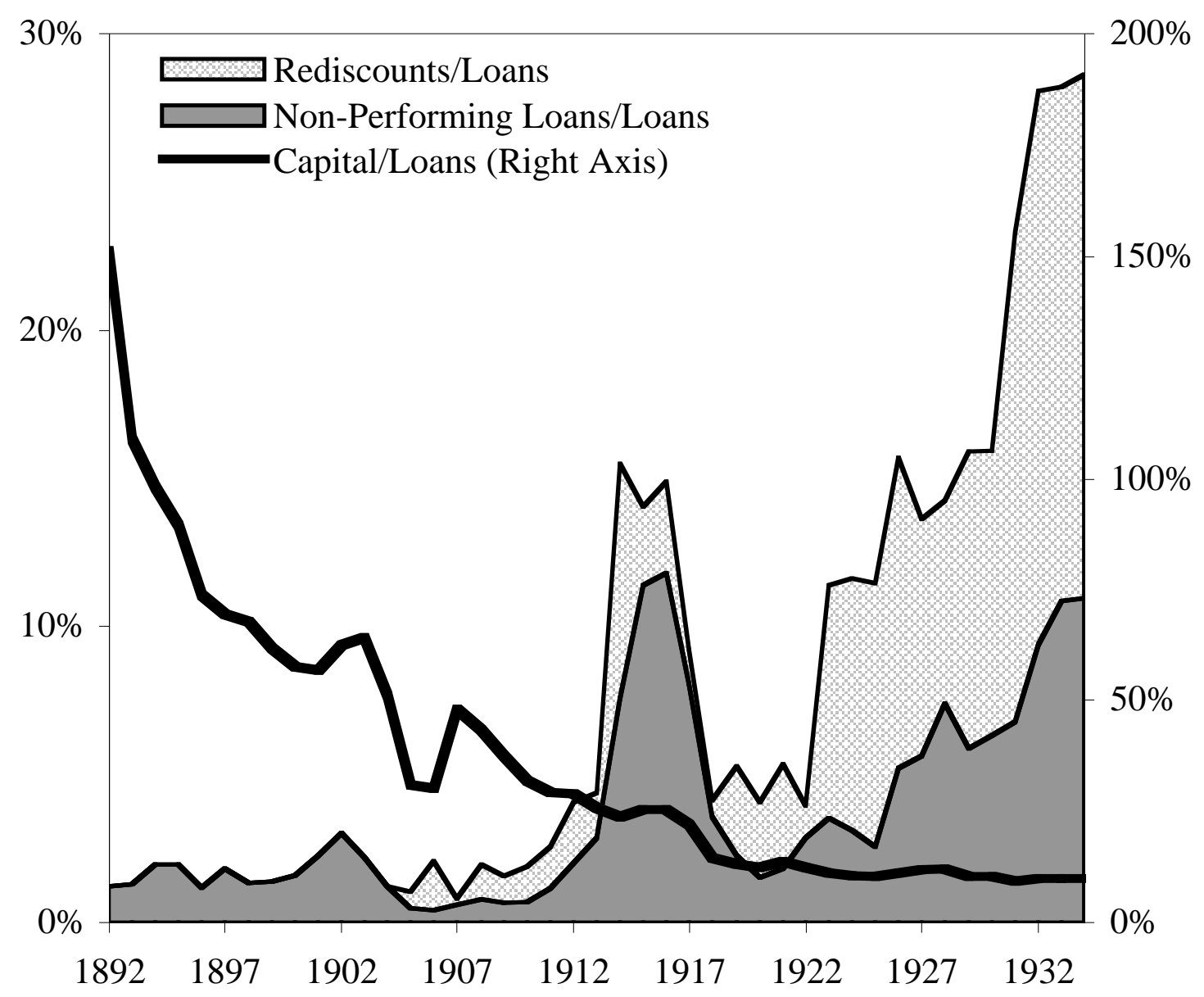




\section{Figure 5}

The rot of bank balance sheets 1914-34:

public versus private debt quality

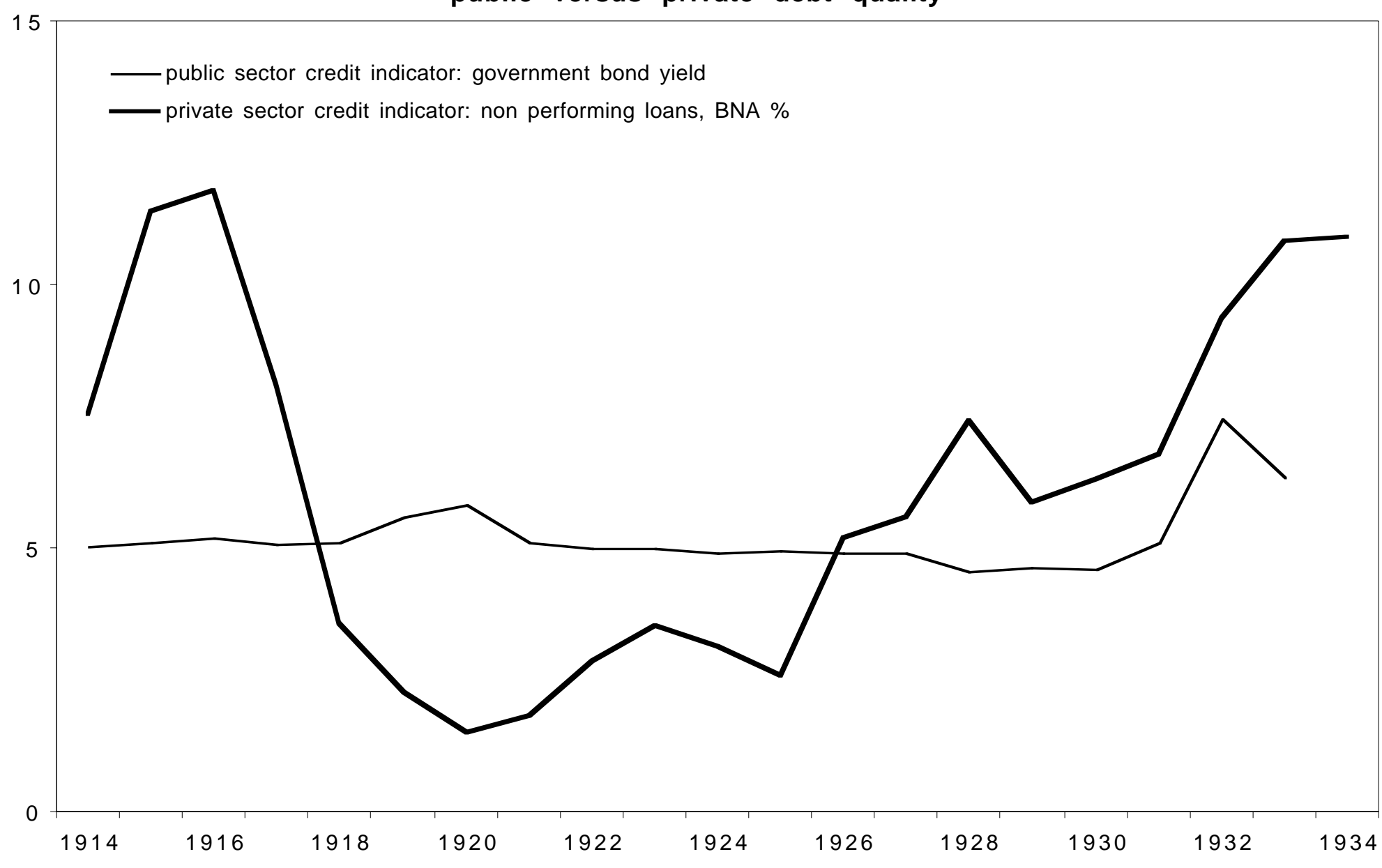


Figure 6

The rot of bank balance sheets 1996-2001

public versus private debt quality

25

— public sector credit indicator: government bond yield

— private sector credit indicator: non performing loans, system \%

——-private sector credit indicator: non performing loans, BNA \%

20

-_-private sector credit indicator: non performing loans, BPBA \%

10



5

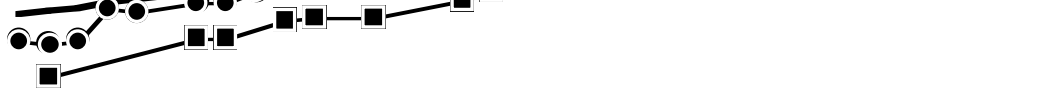

0

Dec-96

Jun-97

Dec-97

Jun-98

Dec-98

Jun-99

Dec-99

Jun-00

Dec-00

Jun-0 1

Dec-01 
Figure 7

The rot of bank balance sheets 1999-2001: public versus private debt quality, impacts

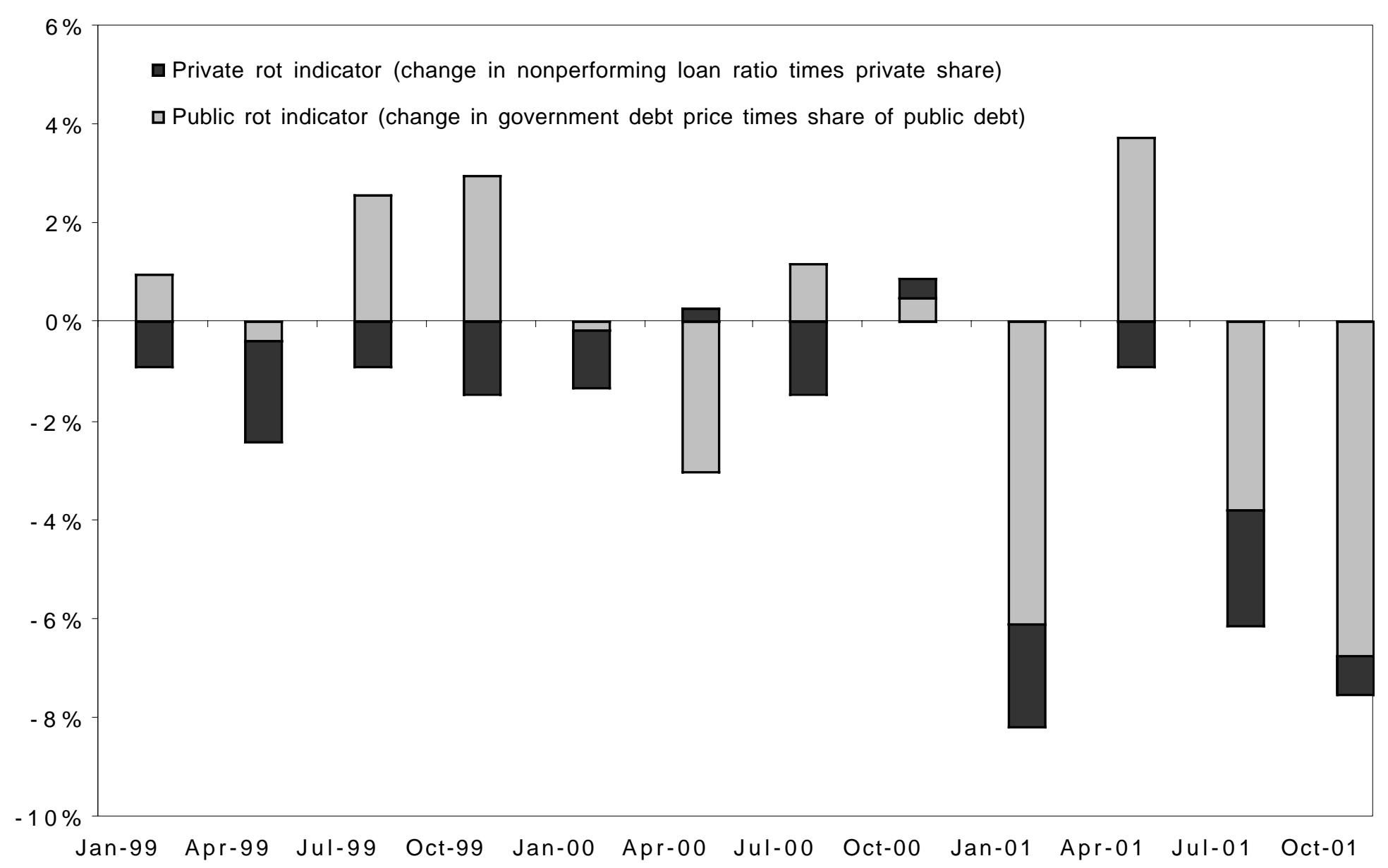




\section{Figure 8}

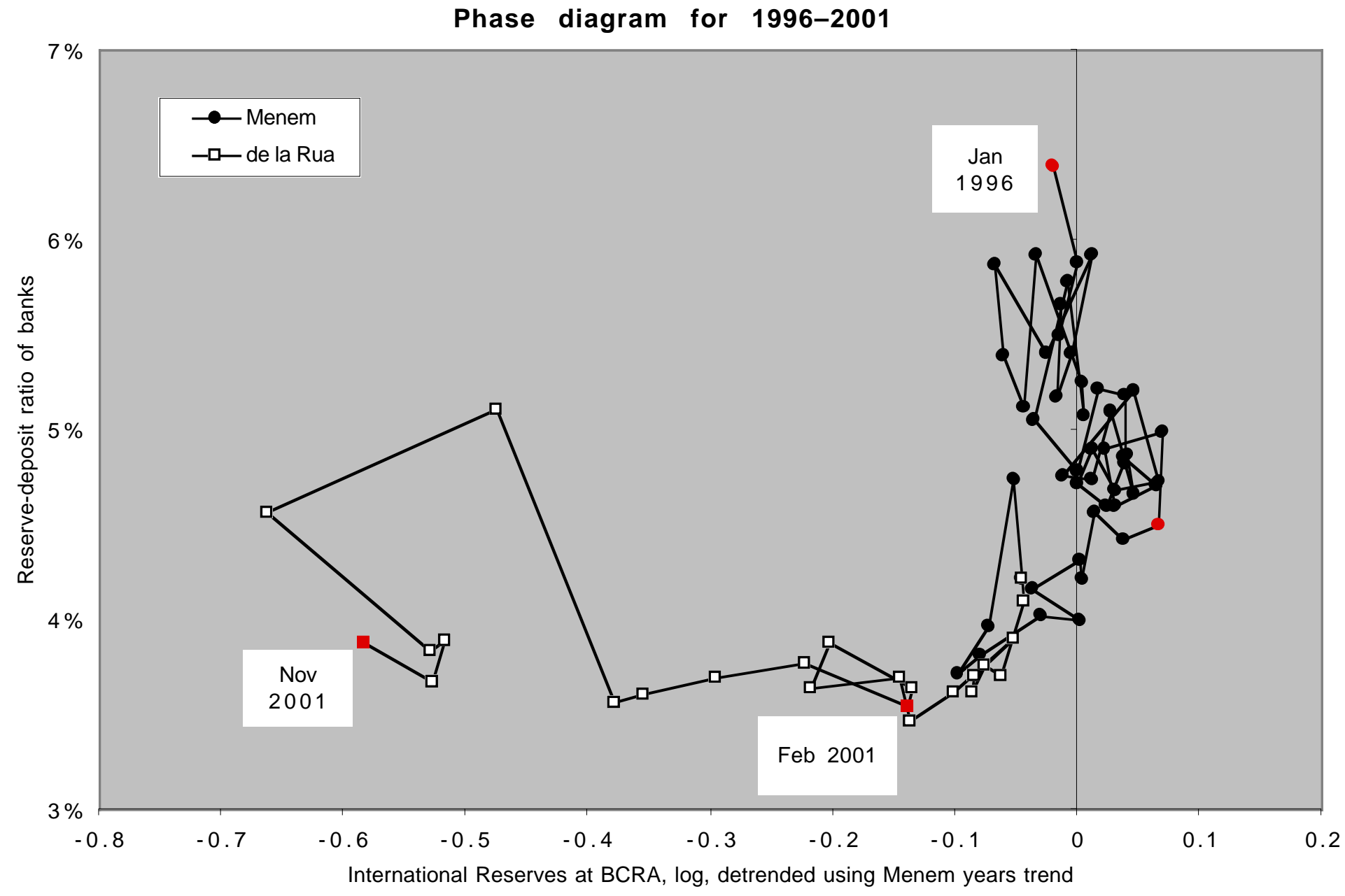




\section{Illustration 1}

\section{The Cure for Gaucho Banking? The "London Consensus" After the Baring Crash}

Caption: “John Bull ordena que los bancos oficiales sean reducidos a cenizas asi prevaleceran en absoluto el Banco de Londres y las ordenes de la City." (John Bull orders that the official banks be reduced to ashes, so that the power of the Bank of London and the orders of The City will prevail.)

Notes: This cartoon is a reference to the massive shock to the financial system during the Baring Crisis that left the domestic banking sector in ruins. Only the foreign banks survived, many of them British. Seat and bank are the same word in Spanish (banco), a play-on-words. Finance Minister Vicente Fidel López (left) and President Carlos Pellegrini (right) make firewood from seats bearing the names of the Banco de la Provincia de Buenos Aires and the Banco Nacional. Already in flames are the other provincial banks. The Englishman supervising the pyre clutches a bag of libras esterlinas (pounds sterling) as teary-eyed financiers look on.

Source: El mosquito, año 28, no. 1473, April 12, 1891.

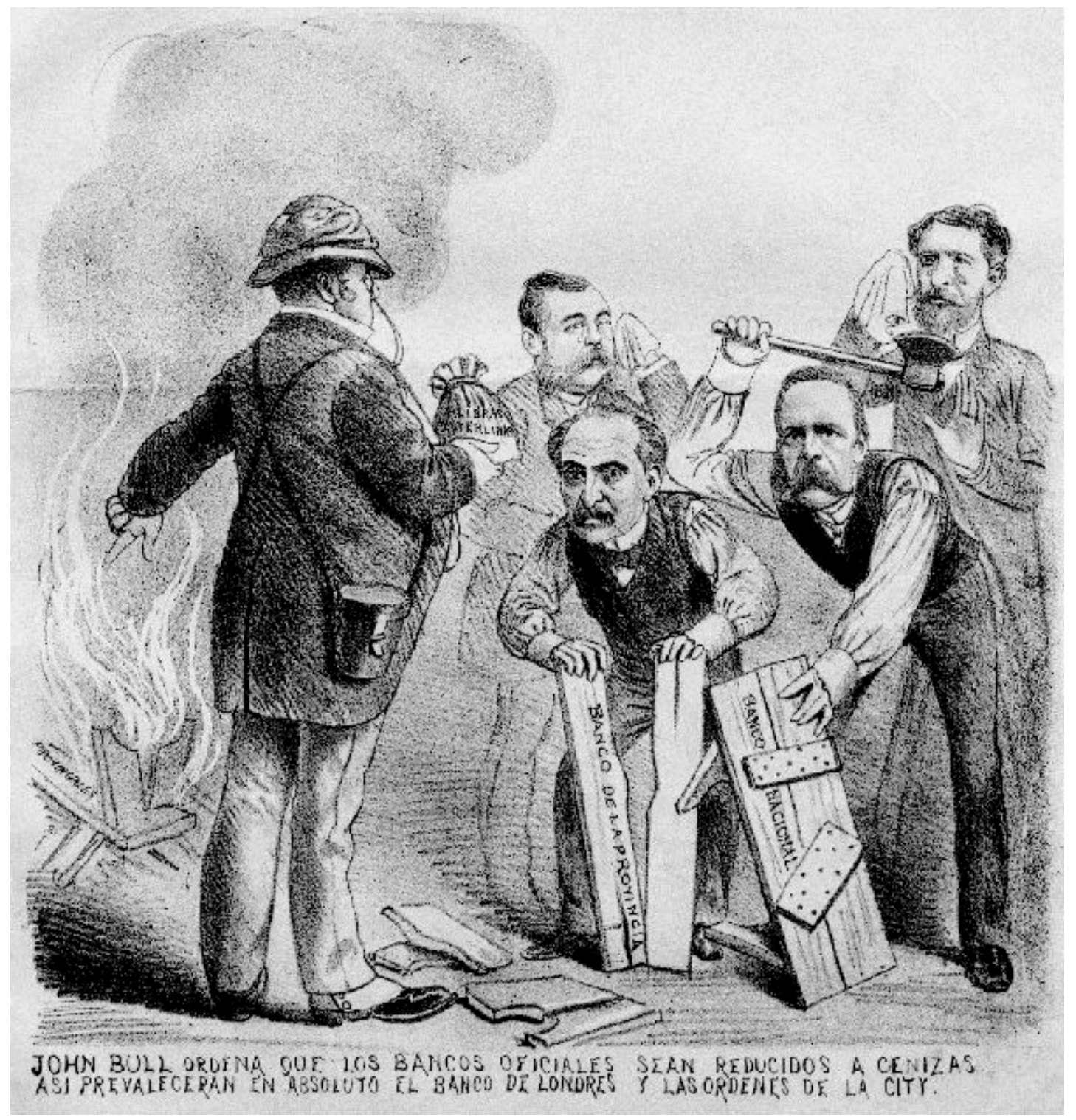

